\title{
Impact of Brand Personality Determinants towards Purchasing Intention: A Study on Branded Umbrella Products in Sri Lanka
}

\author{
Mohamed Riyas $^{1}$ and H.M.R.P. Herath ${ }^{2}$ \\ ${ }^{2}$ Department of Marketing Management, Faculty of Commerce and Management Studies, \\ University of Kelaniya, Sri Lanka (E-mail: renukaherath@kln.ac.lk) \\ ${ }^{1}$ (E-Mail: riyas215@yahoo.com)
}

\begin{abstract}
All Marketing Managers are trying to win the market by differentiating their products among the customers by using the product and brand related factors. Among those factors brand personality is still critical factor to those marketing managers to create the differentiation in the market. Therefore the purpose of this study is explore the relationship of brand personality determinants and purchase intention with referring to the Sri Lankan branded umbrella products. The convenience sampling method was used to collect the primary data. A total of 100 questionnaire were distributed among the umbrella consumers and collected the primary data based on researcher administrated method. Respondent rete is 100\%. Multiple regression analysis used for test the hypotheses. The primary data collected only from Kandy and Colombo Districts among the age limit of 15-45 years umbrella consumers with targeting the only 100 consumers to analysis. The lack of generalization of this study is that it is limited to the branded umbrella industry. Findings of this studies are Excitement and Ruggedness are positively affect to the purchasing intention referring to the branded umbrella products of Sri Lanka. Sincerity, Competence and Sophistication are not positively affect to the purchasing intention referring to the branded umbrella products of Sri Lanka
\end{abstract}

Keywords: Brand Personality and Purchase Intention

\section{Introduction}

Doyle (1990) explain that "distinct brand personality plays a key role in the success of a brand. It leads customers to perceive the brand personality and develop a strong connection to the brand". Govers \& Schoormans (2005) clearly defined that the all marketing activities are aimed at having consumers believe and recognize a brand personality, and reinforcing the communication between the brand and the consumer. Further author (Kumar, 2006) explained that the brand personality should be sharped to be long lasting and consistent. Besides, it should also be different from other brands and meet consumer's demands. Heading (2009) further explained that the "brand personality is derived from human psychology and consumer behavior theories". Brand personality is the differentiated from of brand image, in that sense, while brand 
image represent the tangible benefits and attributes of a brand, brand personality indicates emotional associations of the brand. If brand image is comprehensive brand according to consumers' opinion, brand personality is that aspect of comprehensive brand which generates its emotional character and associations in consumers' mind. Freling \& Forbes (2005) mention that the "brand personality could differentiate and create competitive advantage in consumer's minds for brands that otherwise are indistinguishable from their competitors".

According to the Azoulay \& Kapferer, (2003) brand personality is the set of human personality traits that are both applicable to and relevant for brand. Jenifer \& Aaker, (1997) defined the brand personality as "the set of human characteristics associated with a brand". When Keller (1993) express about brand personality: in contrast to "product related attributes" which tend to serve an utilarian function for consumers, brand personality tends to serve a symbolic or self-expressive function. When consumers use this brands' associations in buying situations, it results in favoring purchase of certain brands. Professor Keller explained the desirable characteristics of brands' association are favorability, vitality and uniqueness. Most of these researchers have done based on developed countries and lack of empirical evidence in the Sri Lankan context related to brand personality and purchase intention based on umbrella industry motivated the researcher to choose this topic. Therefore research problem of this study is to investigate:

'How do the brand personality determinants impact on purchasing intention in branded umbrella products in Sri Lanka?

\section{Research Objectives}

\subsection{Key Objective}

To identify how brand personality determinants impact on purchasing intention of branded Umbrella products in Sri Lanka.

\subsection{Specific Objectives}

i. To carry out the comprehensive theoretical analysis over concept of brand personality, purchasing intention and their relationship.

ii. To critically assess the impact of brand personality towards purchasing intention on branded umbrella products in Sri Lanka

iii. To provide the recommendations to overcome issues on impact of brand personality and purchasing intention related to branded umbrella product in Sri Lanka. 


\section{Literature Review}

There are several Authors have develop deferent definitions to the brand personality and purchasing intention in different situation and different perspectives. Aaker (1997) defined the brand personality as "a set of human characteristics that are associated with the brand". Aaker (1997) advanced a model of the brand personality construct and developed a set of "trait" scales for measuring distinct dimensions of brand personality. But Aaker who make the significant work for the brand personality up to date and still more popular and valid for measuring the nature of a brand's personality (Freling et al., 2011). Aaker defined the brand personality with reference to the big five dimensions and develop the brand personality framework after considering deferent industries. In his brand personality framework he clearly explained the five core dimensions as Sincerity, Excitement, Competence, Sophistication and Ruggedness. Aaker further explained these dimension, Aaker (1997). Sincerity it refers to what extent the brand has down to earth, Honest, wholesome and cheerful characteristics. Excitement it refers daring, spirited, imaginative and up to date characteristics account for the brand to be excited. Competence refers to what extent the brand has reliable, intelligent and successful characteristics. Sophistication explains if the brand has upper class and charming characteristics, such brand is named as sophisticated brand. Ruggedness refers the outdoorsy and tough characteristics account for the brand to be viewed as a rugged.

In other word the most significant issue in each industry concentrate increase purchasing intention. According to Laroche \& Zhol (1996) purchasing intention can be defined as individuals intention on buy a specific brand individuals who want to buy a special brand which they has chosen for themselves after certain evaluation... Lin \& Lin (2007) defined purchase intention is a process to analyze and predict the behavior of consumer. Change \& Crub, (2009) explained purchasing intention as pertaining to consumer willingness to buy; use their extensive attention towards the specific brand. Morwitz, Steckel, \& Gupta (2007) mentioned the situation in which consumer is propelled to purchase a product according to certain condition. Kwek et al. (2010) explained purchase intent to be one attribute concerning with cognitive behavior. Purchase intention scale has been developed from different studies since it is the most important variable in the consumer buying decision. Laroche, Kim \& Zhou (1996) suggest that variables such as customers' consideration in buying a brand and expectation to buy a brand can be used to measure consumer purchase intention. These consideration factors can include the customer's interest, attending, information and evaluation as part of the overall process in determining intention. 


\section{Methodology}

The data for the study was gathered through a questionnaire which was designed based on the literatures that would be synonymous with a brand personality, measuring the Sincerity, Excitement, Competence, Sophistication and Ruggedness. The main purpose of the questionnaire is to measure the impact of brand personality determinants on purchasing intention referring to the branded umbrella products in Sri Lanka. The questionnaire contains three sections which are section A, section B and section $\mathrm{C}$. the section A refer the introductory/ general questions and demographical information and section $\mathrm{B}$ and section Care respectively refer the brand personality related questions based on the Sri Lankan Umbrella brand and purchasing intention related questions. Researcher use the deductive approach and follow the quantitative method through survey techniques. Use the primary data and umbrella consumers as a unit of analysis to collect the data for the study. A total of 100 questionnaire were distributed among the umbrella consumers and collected the primary data based on researcher administrated method. Respondent rete is 100\%. Multiple regression analysis used for test the hypotheses. SPSS data analysis package is used by the researcher to analysis and evaluation.

\section{Conceptual Framework}

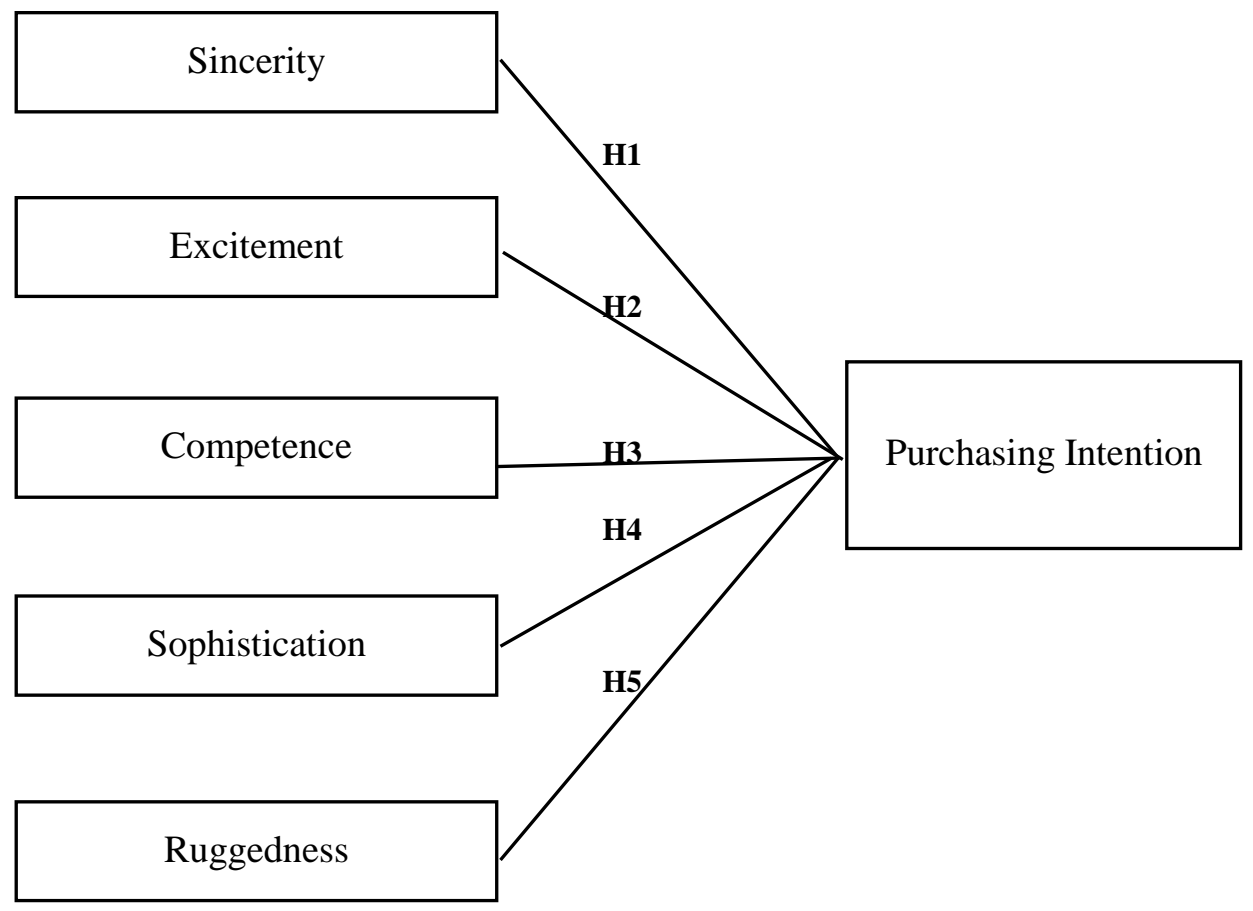




\section{Hypotheses of the Study}

Based on the following researchers, researcher has advanced the following hypotheses. Brand personality has positive influence on brand preference, affection, loyalty and purchase intention-(Mengxia and Chen. Mengxia, 2008 and more distinct brand personality may bring stronger brand loyalty. Since more repurchasing create the brand loyalty-(Chen, 1998).

$\mathbf{H}_{1}$ : Sincerity of the brand personality positively effects on purchasing intention of the customer.

$\mathbf{H}_{2}$ : Excitement of the brand personality positively effects on purchasing intention of the customer.

$\mathbf{H}_{3}$ : Competence of the brand personality positively effects on purchasing intention of the customer.

$\mathbf{H}_{4}$ : Sophistication of the brand personality positively effects on purchasing intention of the customer.

H5: Ruggedness of the brand personality positively effects on purchasing intention of the customer.

\section{Sample}

Considering the umbrella consumers, males and females with reference to age group $15-45$ years from Kandy and Colombo districts. Convenient sampling method will be tested among the 100 target customers.

\section{Data Analysis \& Result}

In this study respondents response $41 \%$ from male and $59 \%$ from female sector. According to the respondents, they can divided in to two districts as Kandy and Colombo. Researcher done the survey in these districts respectively $58 \%$ and $42 \%$. According to the planed sample researcher could find the age category of respondents and they are $45 \%$ from 15-24 years, $46 \%$ from $25-34$ years and $9 \%$ from 35 - 45 years.

\section{Reliability Test}

Result shows that the items of each concept have internal consistency and reliability. The result of the questionnaire reliability analysis show that the Cronbach's alpha value of sincerity is 0.903 , excitement is 0.814 , competence is 0.818 , sophistication is 0.735 , ruggedness is 0.437 and overall Cronbach's alpha value of the questionnaire 
is 0.903 . This result illustrates that the overall consistence of the questionnaire of this study is in high reliability.

Table 01: Reliability Statistics

\begin{tabular}{|l|l|}
\hline \multicolumn{1}{|c|}{ Cronbach's Alpha } & Number of Items \\
\hline .903 & 40 \\
\hline
\end{tabular}

\section{Multiple Regression Analysis}

As researcher planed in the research methodology here we use the multiple regression analysis to test the hypotheses. Following table refers the output of multiple regression analysis of this study.

Table 02: Model Summary

\begin{tabular}{|l|l|l|l|l|}
\hline Model & \multicolumn{1}{|c|}{$\mathrm{R}$} & R Square & Adjusted R Square & Std. Error of the Estimate \\
\hline 01 & $.559^{\mathrm{a}}$ & .312 & .276 & 3.08008 \\
\hline
\end{tabular}

a. Predictors: (Constant), Ruggedness, Excitement, Sincerity, Sophistication, competence

Table 03: ANOVA

\begin{tabular}{|l|c|c|c|c|c|}
\hline \multicolumn{1}{|c|}{ Model } & Sum of Squares & df & Mean Square & F & Sig. \\
\hline 1 Regression & 405.072 & 5 & 81.014 & 8.540 & $.000^{\mathrm{a}}$ \\
Residual & 891.768 & 94 & 9.487 & & \\
Total & 1296.840 & 99 & & & \\
\hline
\end{tabular}

a. Predictors: (Constant), Ruggedness, Excitement, Sincerity, Sophistication, competence

b. Dependent Variable: purchase intention 
Table 04: Coefficients

\begin{tabular}{|c|c|c|c|c|c|c|}
\hline & \multirow{2}{*}{ Model } & \multicolumn{2}{|c|}{$\begin{array}{l}\text { Unstandardized } \\
\text { Coefficients }\end{array}$} & \multirow{2}{*}{$\begin{array}{c}\begin{array}{c}\text { Standardized } \\
\text { Coefficients }\end{array} \\
\text { Beta }\end{array}$} & \multirow{2}{*}{$\mathrm{t}$} & \multirow{2}{*}{ Sig } \\
\hline & & B & Std. Error & & & \\
\hline \multirow[t]{6}{*}{1} & (Constant) & 15.689 & 2.517 & & 6.234 & .000 \\
\hline & Sincerity & .094 & .070 & .153 & 1.347 & .181 \\
\hline & Excitement & .298 & .106 & .352 & 2.813 & .006 \\
\hline & competence & .097 & .119 & .116 & .811 & .419 \\
\hline & Sophistication & -.070 & .125 & -.072 & -.556 & .579 \\
\hline & Ruggedness & -.590 & .207 & -.252 & -2.852 & .005 \\
\hline
\end{tabular}

a. Dependent Variable: purchase intention

Based on the above analysis researcher could found that correlation between observed and predicted values of dependence variable is 0.559 alpha. Root mean squared error is 3.08 and ANOVA $^{\mathbf{b}}$ explains the analysis of above output as regression 405.072, residual 891.768 and total value refers 1296.840. Furthermore will explain through the hypotheses test.

\section{Hypotheses Testing}

Based on the table 6 of multiple regression analysis all the hypotheses will be tested.

$\mathbf{H}_{1}$ : Sincerity of the brand personality positively effects on purchasing intention of the customer.

Considering the report of SPPS as above researcher could found that the sincerity represent the $\mathrm{B}$ value 0.094, $\mathrm{t}$ - value 1.347, and significant value 0.181. Coefficient of independent variable sincerity is 0.094 significantly different from 0 be course its $\mathrm{P} / \mathrm{Sig}$. value is 0.181 . Significant value 0.181 is greater than 0.05 .it refers that the independent variable sincerity is not positively effects on purchasing intention. So, hypothesis [H1] one is tested and it is rejected. 
$\mathbf{H}_{2}$ : Excitement of the brand personality positively effects on purchasing intention of the customer

Considering the report of SPSS as above researcher could found that the Excitement represent the $\mathrm{B}$ value 0.298 , $\mathrm{t}$ - value 2.813 , and significant value 0.006 . Coefficient of independent variable Excitement is 0.298 significantly different from 0 be course its P/ Sig. value is 0.006 . Significant value 0.006 is less than 0.05 . It refers that the independent variable Excitement is positively effects on purchasing intention. So, hypotheses [H2] two is tested and it is accepted.

$\mathbf{H}_{3}$ : Competence of the brand personality positively effects on purchasing intention of the customer

Considering the report of SPSS as above researcher could found that the Competence represent the $\mathrm{B}$ value $0.097, \mathrm{t}$ - value 0.811 , and significant value 0.419 . Coefficient of independent variable Competence is 0.097 significantly different from 0 be course its P/ Sig. value is 0.419 . Significant value 0.419 is greater than 0.05 . It refers that the independent variable Competence is not positively effects on purchasing intention. So, hypotheses [H3] 03 is tested and it is rejected.

$\mathbf{H}_{4}$ : Sophistication of the brand personality positively effect on purchasing intention of the customer

Considering the report of SPSS as above researcher could found that the Sophistication represent the B value -0.070 , $\mathrm{t}$ - value -0.556 , and significant value 0.579 . Coefficient of independent variable Sophistication is -0.070 significantly different from 0 be course its P/ Sig. value is 0.419 . Significant value 0.579 is greater than 0.05. It refers that the independent variable Sophistication is not effects on purchasing intention. So, hypotheses [H4] 04 is tested and Sophistication is not positively affect the purchasing intention.

H5: Ruggedness of the brand personality positively effect on purchasing intention of the customer

Considering the report of SPSS as above researcher could found that the Ruggedness represent the $B$ value -0.590 , $t$ - value -2.852 , and significant value 0.005 . Coefficient of independent variable. Ruggedness is -0.590 significantly different from 0 be course its P/ Sig. value is 0.005 . Significant value 0.005 is less than 0.05 . It refers that the independent variable Ruggedness is positively effects on purchasing intention. So, hypotheses [H5] 05 is tested and Ruggedness is positively affects the purchasing intention and it is accepted. 


\section{Findings and Recommendations}

According to the hypotheses testing result of the study researcher could found that the Excitement and Ruggedness are positively affect to the purchasing intention referring to the branded umbrella products of Sri Lanka. Sincerity, Competence and Sophistication are not positively affect to the purchasing intention referring to the branded umbrella products of Sri Lanka.

\subsection{Managerial Implication}

Referring to the findings of this studies some brand personality determinants are positively affect to the purchasing intention of branded umbrella products in Sri Lanka and some are not. Those positively affecting variables can be practiced in product designing process. All Managers and executives of production division have to consider these factors when designing and developing the product. Marketing managers also should consider these factors well in developing and practicing marketing activities refer to the brand. Be course brand personality leads the consumer towards to the brand loyalty. Which will provide the benefits to the organizations.

\subsection{Further Research}

Change the different products and brand and find the impact of the brand personality to implement the customer loyalty to win the market.

Change the industry to be studied in new research: since this study refer only the branded umbrella industry, sometime this finding may affect different way for some other industry and this finding may useful for those who hope to do in the field of research related to the brand personality.

\section{Limitations of the Study}

The restraint of the sampling coverage: The questionnaire survey was only conducted at Kandy and Colombo Districts among the age limit of 15-45 years umbrella consumers. Even with in that testing area targeting the only 100 consumers to analysis the factors.

The lack of generalization of the study findings: This study is limited to the branded umbrella industry. It is unknown if the result can be applied to other industries. Thus further investigation is required if planning to apply the results to other industries 


\section{References}

Aaker J. (1997) "Dimension of Brand Personality", journal of Marketing Research, 34(August), 347-357 http://dx.doi.org/10.2307/3151897

Azoulay, A \& Kapferer, J.N. (2003, November). Do brand personality scales really measure brand personality? Brand Management, 11, 143-155

Biel, A. (1992), "How brand image drives brand equity", Journal of Advertising Research, Vol. 32 No. 6, November/December, pp. RC6-RC12

Changa, H. H., \& Liub, Y. M. (2009). The impact of brand equity on brand preference and purchase intentions in the service industries. The Service Industries Journal, 9(12), 1687-1706. http://dx.doi.org/10.1080/02642060902793557

Doyle, P. (1990), "Building successful brand: the strategic option", Journal of Consumer Marketing, Vol. 7 No 2, pp. 5-20 http://dx.doi.org/10.1108/EUM0000000002572

Freling, T. H., Crosno, J. L., \& Henard, D. H. (2011). Brand personality appeal: conceptualization and empirical validation. Journal of the Academy of Marketing Science, 39(3), 392-406 http://dx.doi.org/10.1007/s11747-010-0208-3

Freling T. H., and Forbes L. P. (2005). An empirical analysis of the brand personality effect. Journal of Product and Brand Management, 14 (7), pp 404-413. http://dx.doi.org/10.1108/10610420510633350

Govers, P.C.M. and Schoormans, J.P.L. (2005), "Product personality and its influence on consumer preference", journal of consumer marketing, Vol.22 No. 4, pp 189-97 http://dx.doi.org/10.1108/07363760510605308

Heding, T., F.Knudtzen, C., \&Bjerre, M. (2009). Brand management: research, theory and practice. UK: Routledge

Johnson,M.D. and Puto, C.P. (1987), "A review of consumer judgement and choice", in Houston, M. (Ed.), Review of Marketing, American Marketing Association, Chicago, IL, pp. 236-92.

Joseph T. Plummer (1984/85), "How personality makes a Difference", Journal of Advertising Research, 24, 6, December/ January, 27-31

Keller, K.L. (2003), Strategic Brand Management: Building, Measuring, and Managing Brand Equity.

Keller,K.L. (1993) "Conceptualizing, Measuring and Managing Customer based Brand Equity", Journal of Marketing, 57 January, 1-22 http://dx.doi.org/10.2307/1252054

Kim, H. B., Kim, W. G. \& An, A. J. (2003). The effect of consumer based brand equity on firm's financial performance. Journal of Consumer Marketing, 20(4), 335-351. http://dx.doi.org/10.1108/07363760310483694 
Kumar, R., Luthra, A and Datta, G (2006), "Linkages between brand personality and brand loyalty: a qualitative study in an emerging market in the Indian context", South Asian Journal of Management, Vol.13 No.2, pp. 11-35

Kwek.C.L, Tan,H.P, Teck-Chai Lau (2010). Investigating the Shopping Orientations on Online Purchase Intention in the e-Commerce Environment: A Malaysian Study, JIBC, Vol. 15, No.2

Lin, N.-H., \& Lin, B.-S. (2007). The Effect of Brand Image and Product Knowledge on Purchase Intention Moderated by Price Discount. Journal of International Management Studies, 121-132.

Louis, D., \& Lombart, C. (2010). Impact of brand personality on three major relational consequences (trust, attachment, and commitment to the brand). Journal of Product \& Brand Management, 19(2), 114-130. http://dx.doi.org/10.1108/10610421011033467

Laroche, Kim and Zhou (1996), Brand familiarity and confidence as determinants of purchase intention: An empirical test in a multiple brand context, Journal of Business Research, Vol.37, No.2, 115-120

Morwitz, V. G., Steckel, J. H., and Gupta, A. (2007). When do purchase intentions predict sales? International Journal of Forecasting, 23, 347-364

Paurav Shukla. (2009), "Impact of contextual factors, brand loyalty and brand switching on purchase decisions", Journal of Consumer Marketing, Vol. 26 No.5, pp. 348-357. http://dx.doi.org/10.1108/07363760910976600

Temporal, P. (2011). Islamic Branding and Marketing: Creating a Global Islamic Business. United States: Wiley

Tuan, L. Y., Tat, H. H., Shamsuddin, A. S., Rasli, A. M., \& Jusoh, A. (2012). Potential of Brand Personality: Attachment Styles as Moderator. American Journal of Business and Management, 1(3), 34-42. http://dx.doi.org/10.11634/ajbm.20130201.01

Yang, Y. T. (2009). A study of purchase intention behavior to consumers on innovation technology smart phone in technology acceptance model and theory of reason action. Unpublished master thesis, Nan Hua University, Taiwan

Zeithaml, V. A. (1988), Consumer perceptions of price, quality and value: a means-end model and synthesis of evidence. Journal of Marketing, 52, 2-22. http://dx.doi.org/10.2307/1251446 